\title{
Preparation and characterization of a thermoplastic proton- exchange system based on SEBS and polypropylene blends
}

\author{
K. Polat ${ }^{*}$, M. Şen ${ }^{2}$ \\ ${ }^{1}$ Dokuz Eylül University, Department of Chemistry, Physical Chemistry division, 35390 Tinaztepe, İzmir, Turkey \\ ${ }^{2}$ Hacettepe University, Department of Chemistry, Polymer Chemistry Division, 06800 Beytepe, Ankara, Turkey
}

Received 3 September 2016; accepted in revised form 3 November 2016

\begin{abstract}
The paper focuses on a series of blends prepared with different contents of polystyrene-block-poly-(ethylene-ranbutylene)-block-polystyrene (SEBS) and polypropylene (PP) for the purpose of examining the potential as proton exchange membranes. Polymer blends were prepared by twin-screw extrusion and then compressed by means of a hot-press device into thin films of $125 \mu \mathrm{m}$ and then ionic sides were created by solid state sulfonation in a chlorosulfonic acid solution. Obtained films were characterized by means of water-uptake, mechanical properties, ion-exchange capacities (IEC) and ion conductivities. It was observed that the rigidity of the films increased with rising sulfonation durations. However humidity absorption from the air decreased the rigidity at high sulfonation levels. Improved water uptake values were obtained when compared to previously reported values in the literature. On the other hand ion exchange values showed an increase parallel to the sulfonation duration up to 45 minutes, but a decrease thereafter was observed due to the diffusion of some sulfonated polymer chains into the ion-exchange medium thereby calculated ion exchange values of S-SEBSH45 and S-SEBSH60 were found less than expected. All films showed ion conductivities up to $432 \mathrm{mS} / \mathrm{cm}$ at $25^{\circ} \mathrm{C}$. Only S-SEBSH45 and S-SEBSH60 were successful in conducting protons at $80^{\circ} \mathrm{C}$ owing to the high water retaining capacity.
\end{abstract}

Keywords: polymer blends and alloys, proton conductivity, proton-exchange films, fuel cell, polymer membranes

\section{Introduction}

Proton-exchange membranes are critical components of fuel cells. Their properties strongly affect the performance of the cells. An ideal fuel-cell membrane should exhibit properties such as good mechanical and chemical durability, high proton conductivity at low temperatures, low fuel permeability from anode side to cathode side during operation and low cost [1]. Unfortunately, there is no membranes available to fulfill all of these characteristics. Nonetheless, several of the commercially available membranes satisfy most of the industry requirements for a feasible fuel cell production. Among them, the Nafion ${ }^{\circledR}$ is well recognized but expensive one and thus significant efforts have been targeted at the development of costeffective counterparts [2]. Among them, polybenz- imidazole based proton exchange membranes such as sulfonated oxy-polybenzimidazole (S-OPBI) with controlled swelling characteristics and comparable ion exchange values for room temperature applications can be mentioned [3]. Phosphoric acid doped polybenzimidazole polymers can be used also at high temperature up to $170-200^{\circ} \mathrm{C}$ however some disadvantages such as phosphoric acid doping limitation caused by molecular structure, prerequisite for using phosphoric acid resistive, very expensive noble metal catalyts, mechanical drawbacks and phosphoric acid leaching during operation $[4,5]$ are waiting to be improved although some promising studies have been realised in the past few years $[6,7]$.

Polystyrene-block-poly(ethylene-ran-butylene)-blockpolystyrene (SEBS), a three-block copolymer, is a

"Corresponding author, e-mail: kinyas.polat@,deu.edu.tr C BME-PT 
potentially cheaper alternative to Nafion ${ }^{\circledR}$ owing to its abundance, low cost and its ability of exhibiting elastomer/thermoplastic duality for an easy processing [8]. Although SEBS allows high proton conduction through the sulfonation of the styrene units, difficulties in film casting of its pure form and the high water uptake of sulfonated SEBS in the presence of water hinders the efforts to convert it to a proton-exchange film $[9,10]$. Nonetheless, several studies observed low water uptake and good mechanical properties by blending SEBS with hydrophobic polymers such as polyvinylidene fluoride (PVDF) or high-density polyethylene [11, 12]. However, these studies failed to provide evidence for the stability of such blends, which results in highly incompatible components, before and after sulfonation.

SEBS can actually form compatible blends other than PVDF and high density polyethylene (HDPE), and one such well-known industrial blend of the SEBS consists of polypropylene and wax which is used in household devices and automobile parts due to its superior properties over SEBS or PP, i.e. easy processability, high compatibility and mechanical stability [13]. Venestra et al. [14] showed that such blends maintain a co-continuous morphology when SEBS content is more than $20 \%$, and a droplet-matrix morphology if the SEBS content is less than $20 \%$ at $190^{\circ} \mathrm{C}$ annealing temperature. Mae and Omiya [15] showed that blends with less than 20\% SEBS content exhibit crazing, whereas crazing is absent for SEBS content higher than $20 \%$ owing to morphology changes. Ohlsson et al. [16] observed that blends with co-continuous morphology have elastomeric behaviour but fail to maintain this behaviour when the droplet-matrix morphology is dominant. A more detailed analysis of the characteristics of such blends has been performed by Sengupta and Noordermeer [17] who prepared all possible combinations of SEBS/ PP/WAX blends and found that tensile strength decreased as the wax content increased. In contrast, the tensile strength and $E$-modulus increased by addition of PP up to $35-40 \%$. However, this was not observed at higher PP content. The effect of SEBS content strongly depended on the dimensions of SEBS domains in the matrix and the amount of applied shear stress exerted in the preparation steps. An increase in shear stress reduces the domain size, which results in higher elongation and higher tensile strength.
To the best of our knowledge, no study has focused on the possibility of using the low cost and readily available blends of SEBS with PP in proton-exchange film preparation. Hence, we examined these blends as promising proton-exchange films that might be used in fuel cell applications. For this purpose, we produced two blends differing in SEBS, PP and wax composition. The first, SEBSL consisted of $35 \%$ SEBS, $10 \%$ PP, $54 \%$ wax and $1 \%$ stabilizer, whereas the second, SEBSH consisted of $70 \%$ SEBS, $5 \%$ PP, $24,5 \%$ wax and $0.5 \%$ stabilizer. PP used to increase solvent resistance, mechanical strength and optical transparency. The purpose of using wax in the blend was the processing aid. The stabilizer was used for preventing thermo-oxidative degradation.

\section{Experimental}

\subsection{Materials}

SEBS (kinematic viscosity: $1500 \mathrm{cP}$ ) consisting of $31.5 \%(\mathrm{w} / \mathrm{w})$ styrene and $68.5 \%(\mathrm{w} / \mathrm{w})$ ethylenebutylene obtained from Kraton Performance Polymers Inc., Texas, USA with a molecular weight of $95000 \mathrm{~g} / \mathrm{mol}$. Wax (Finewax EI) was purchased from Fine Organics, Mumbai, India. Polypropylene PP (MH 418) was purchased from Petkim Petrokimya Holding A.Ş, İzmir, Turkey, having 4-6 g/10 min melt flow index. Stabilizer (Irganox) which is made up of pentaerythritol tetrakis(3-(3,5-di-tert-butyl-4hydroxyphenyl)propionate) in the form of granules with a melting point of $85^{\circ} \mathrm{C}$ was purchased from BASF S.A. Chlorosulfonic acid and 1,2-dichloroethane was purchased from Sigma-Aldrich Co. LLC. and Merck \& Co., respectively.

\subsection{Preparation of films}

Components of the blends were mixed mechanically and extruded into films by using a Reomex OS model (Thermo-Haake) laboratory-type twin screw extruder at $80 \mathrm{~g} / \mathrm{min}$ feeding speed, and the average retaining time in the extruder barrel was adjusted to $1 \mathrm{~min}$ [13-15]. The temperature of the extruder was kept at $180^{\circ} \mathrm{C}$ at the entrance, $210^{\circ} \mathrm{C}$ in the middle and $180^{\circ} \mathrm{C}$ at the exit. The maximum die slit distance at the exit was $500 \mu \mathrm{m}$. To obtain further thinner films a rolling-stretching unit was placed in front of the die at $30 \mathrm{~cm}$ distance and therefore films could further be drawn to $300 \mu \mathrm{m}$. Eventually $125 \mu \mathrm{m}$ thickness was obtained by using hot-press machine at $4.107 \mathrm{~Pa}$ and $190^{\circ} \mathrm{C}$ for $1 \mathrm{~min}$ [18]. 


\subsection{Preparation of sulfonated films}

Sulfonation of the styrene side-units means that the replacement of $(-\mathrm{H})$ atoms with the $\left(-\mathrm{SO}_{3}\right)$ groups on the benzene rings in SEBS chains as much as possible. This creates proton conduction sides for the protons. SEBSL and SEBSH films were thus sulfonated by immersing in $0.9 \mathrm{M}$ chlorosulfonic acid solution in 1,2-dichloroethane for several durations at $4{ }^{\circ} \mathrm{C}$ without sunlight. Films were then neutralized as soon as taken out of from sulfonation solution by immersing into methanol-water mixture and then washed throughly with excess deionized water. The sulfonated films were kept in water for subsequent analysis [11]. Figure 1 illustrates the structural formula of sulfonated SEBS (S-SEBS). Names of the sulfonated films bear a (S-) prefix for indication of sulfonated films and a number as a suffix showing their sulfonation durations in minutes. Representative photograps of dried sulfonated films are given in Figure 2, as the sulfonation degree increased, the color of the films become darker.

\subsection{Proton conductivity measurements}

Proton conductivity was measured in a fuel-cell test device (Teledyne Medusa) by using a setup including Solartron SI 1260 frequency gain analyzer, a Solartron SI 1287 electrochemical interface and a fourprobe in-plane conductivity test cell. The sulfonated films were equilibrated in deionized water for 24 hours and then placed in test cell which is kept at $100 \%$ humidity level by circulating humidified nitrogen gas. Conductivity was measured between 0.1 and

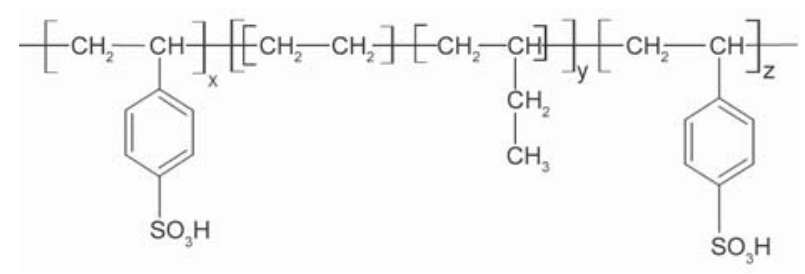

Figure 1. Structure of S-SEBS

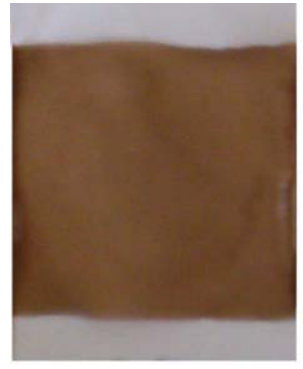

S-SEBSH2

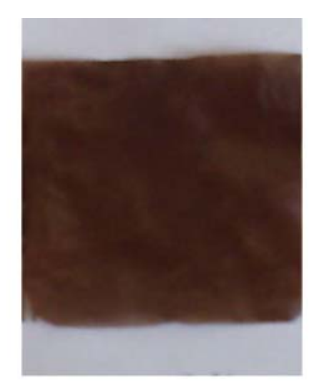

S-SEBSH5

$100 \mathrm{~Hz}$ where the applied AC voltage was maintained at $10 \mathrm{mV}$ [9-12] at 25 and $80^{\circ} \mathrm{C}$.

\subsection{Thermal stability measurements}

Thermal stabilities of the films were evaluated by thermal analysis via Perkin Elmer (Pyris 1 TGA) by heating in nitrogen atmosphere at $20^{\circ} \mathrm{C} / \mathrm{min}$ up to $600^{\circ} \mathrm{C}$.

\section{Results and discussion}

\subsection{ATR-FTIR characterization}

FTIR spectra of the membranes were collected by using a Nicolet 6700 spectrometer with an ATR module from 400 to $4000 \mathrm{~cm}^{-1}$ in 64 scans. Figure 3 shows the FTIR spectrum for the SEBSH blend.

The absorbance at $696 \mathrm{~cm}^{-1}$ represents the out-ofplane bending of $\mathrm{C}-\mathrm{H}$ bonds in the aromatic ring [14]. The absorbance at $1455 \mathrm{~cm}^{-1}$ is attributed to the asymmetric stretching of $\mathrm{C}-\mathrm{H}$ bonds in the $\mathrm{CH}_{3}$ groups of the ethylene-butylene blocks in SEBS and PP. The peak at $1372 \mathrm{~cm}^{-1}$ represents the deformation vibrations of the $\mathrm{C}-\mathrm{H}$ bonds in the $\mathrm{CH}_{2}$ groups $[19,20]$. The absorptions at 2850 and $2921 \mathrm{~cm}^{-1}$ belong to the symmetric and asymmetric vibrations of the $\mathrm{C}-\mathrm{H}$ bonds in the $\mathrm{CH}_{2}$ groups, respectively [21]. After sulfonation, several new peaks are observed, as shown in Figure 4 for the S-SEBSH2. The absorbance at 6721,1124 and $1164 \mathrm{~cm}^{-1}$ is due to the vibrations of the sulfonic acid groups in the aromatic rings following the sulfonation reaction. The peaks at 1006 and $1035 \mathrm{~cm}^{-1}$ represent the vibrations of the substituted aromatic ring [9]. The wide absorbance peak between $3200-3600 \mathrm{~cm}^{-1}$ is attributed to the $\mathrm{O}-\mathrm{H}$ bond vibrations [22]. The assessment of the FTIR spectra suggests that the sulfonation was successfully carried out.

\subsection{Mechanical characterization}

The mechanical properties of the films were tested by means of Zwick Z010 tensile tester and a Zwick

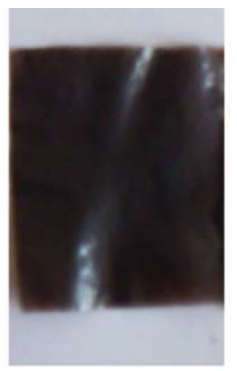

S-SEBSH45

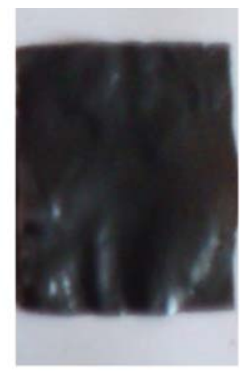

S-SEBSH6O

Figure 2. Photographs of sulfonated films 


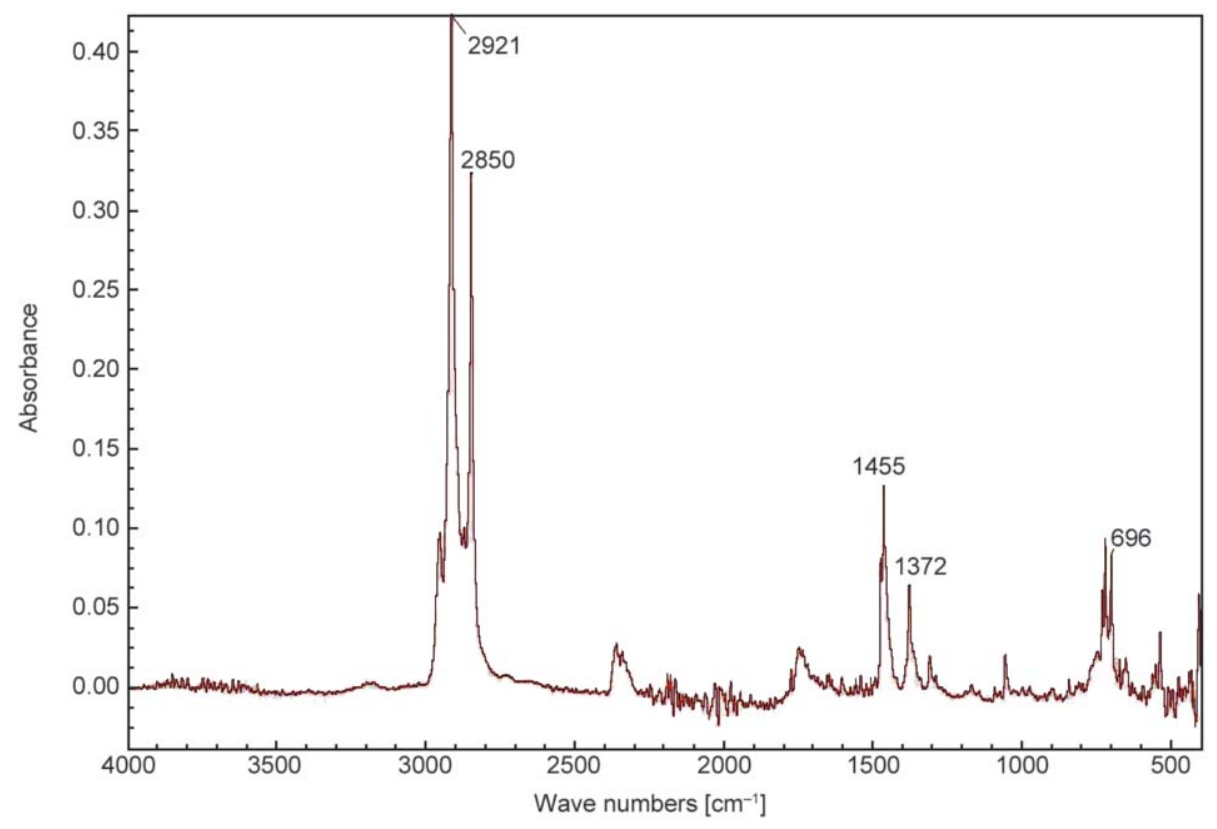

Figure 3. FTIR spectrum for the SEBSH

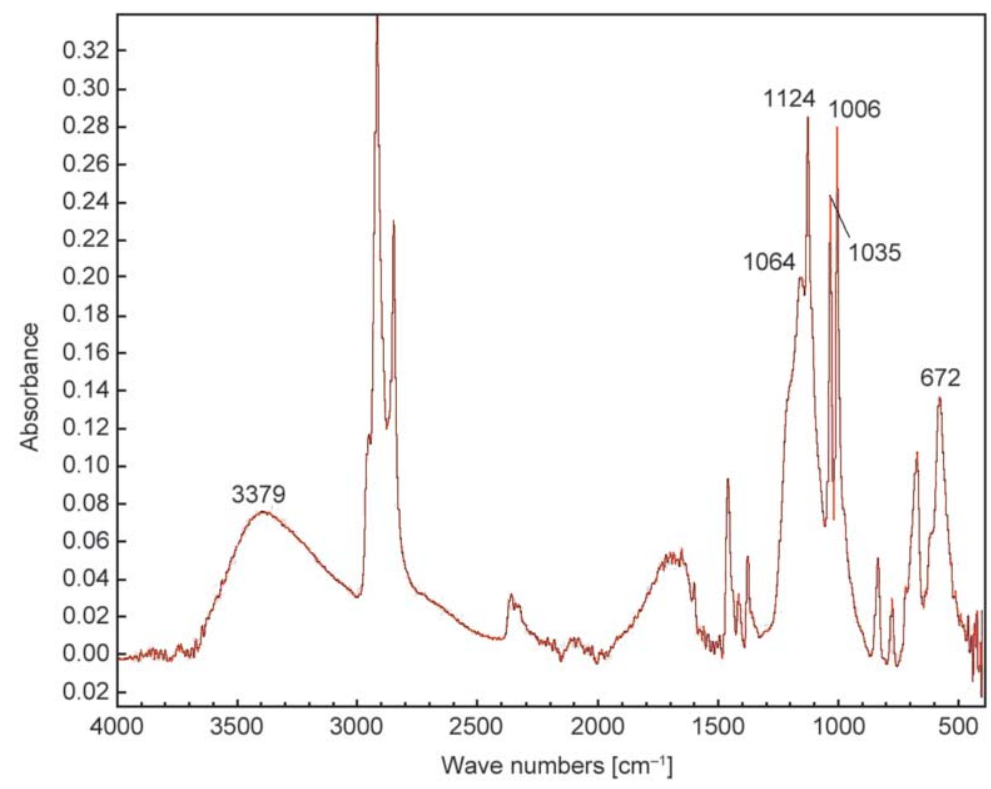

Figure 4. FTIR spectrum of the S-SEBSH2

B.005 (ISO 37) specimen cutting mold. The length of specimen cutting mold was $2 \mathrm{~cm}$. Mechanical test results for the samples were given in Table 1 .

As shown in Table 1, E-modulus value for SEBSL is almost two times greater than SEBSH due to the rigidity enhancement introduced by higher PP content. There is a linear increase in the $E$-modulus (rigidity) values with increasing sulfonation in all of the films except S-SEBSH60 in which the value is less than expected. Some degradation is believed to be responsible for this drop at longer sulfonation durations due to the very corrosive nature of the chlorosulfonic acid. The same situation is valid for the frac- ture stress. $E$-modulus values of SEBSL and SEBSH films drastically increased when they sulfonated. Sulfonation increases the $E$-modulus values approximately ten times when compared to the non-sulfonated forms of the films, S-SEBSL2/3/4/5 films showed higher $E$-modulus values than that of $\mathrm{S}$ SEBSH2/3/4/5/45/60 films although their sulfonation degrees are lower, which shows that contribution of PP was not overcome by sulfonation. The possible reason might be moisture absorption from air since highly sulfonated films are expected to absorb much moisture, which softens them and undermines the mechanical strength. It was observed that 
Table 1. Mechanical properties

\begin{tabular}{|l|c|c|c|c|c|c|c|c|}
\hline Film names & $\begin{array}{c}\text { SEBS } \\
{[\mathbf{\%}]}\end{array}$ & $\begin{array}{c}\mathbf{P P} \\
{[\mathbf{\%}]}\end{array}$ & $\begin{array}{c}\text { Wax } \\
{[\mathbf{\%}]}\end{array}$ & $\begin{array}{c}\text { Sulfonation } \\
{[\mathbf{m i n}]}\end{array}$ & $\begin{array}{c}\text { Sulfonation } \\
{[\mathbf{\%}]}\end{array}$ & $\begin{array}{c}\boldsymbol{E} \text {-modulus } \\
{[\mathbf{M P a}]}\end{array}$ & $\begin{array}{c}\text { Elongation at break } \\
{[\mathbf{\%}]}\end{array}$ & $\begin{array}{c}\text { Fracture stress } \\
{[\mathbf{M P a}]}\end{array}$ \\
\hline S-SEBSL2 & 35 & 10 & 54.0 & 2 & 8.55 & 51.5 & 575 & 25.5 \\
\hline S-SEBSL3 & 35 & 10 & 54.0 & 3 & 9.51 & 54.4 & 595 & 27.1 \\
\hline S-SEBSL4 & 35 & 10 & 54.0 & 4 & 11.40 & 67.8 & 537 & 27.6 \\
\hline S-SEBSL5 & 35 & 10 & 54.0 & 5 & 12.40 & 78.0 & 477 & 30.8 \\
\hline S-SEBSH2 & 70 & 5 & 24.5 & 2 & 40.80 & 20.2 & 789 & 24.3 \\
\hline S-SEBSH3 & 70 & 5 & 24.5 & 3 & 64.50 & 27.0 & 593 & 18.8 \\
\hline S-SEBSH4 & 70 & 5 & 24.5 & 4 & 65.20 & 29.0 & 554 & 19.0 \\
\hline S-SEBSH5 & 70 & 5 & 24.5 & 5 & 97.50 & 33.0 & 504 & 18.1 \\
\hline S-SEBSH45 & 70 & 5 & 24.5 & 45 & 87.30 & 35.0 & 406 & 21.8 \\
\hline S-SEBSH60 & 70 & 5 & 24.5 & 60 & 76.40 & 32.0 & 311 & 13.7 \\
\hline SEBSL & 35 & 10 & 54.0 & - & - & 6.0 & 1406 & 14.9 \\
\hline SEBSH & 70 & 5 & 24.5 & - & - & 3.4 & 1461 & 18.2 \\
\hline Pure SEBS & 100 & 0 & 0 & - & - & 2.7 & 1148 & 42.0 \\
\hline PP & 0 & - & 0 & - & - & 1800.0 & 150 & 30.0 \\
\hline
\end{tabular}

fracture stress influenced also in the same way. As we look at the elongation values, there is a descending relationship with sulfonation. For SEBSL and SEBSH blends, we see high elongation owing to their elastomeric nature. Unfortunately, the rigidity introduced by sulfonation caused some loss of elastomeric character of the films reducing the elongation values almost to half of SEBSL and SEBSH films have. This situation can also be associated with the formation of phase segregation tunnels between hydrophilic sulfonated styrene groups and hydrophobic aliphatic chains of PP that weakens the mechanical durability [23].

\subsection{Sulfonation degree, water uptake, ion-exchange capacity (IEC) and thermal stability}

Sulfonation degree is calculated by using available styrene groups in the membranes and weight increase after sulfonation. Sulfonated styrene groups is determined by weight increase $\left(\mathrm{SO}_{3}\right.$ group is responsible for weight increase) as described in the Equation (1):

Sulfonation degree $[\%]=$

$$
=\frac{M_{\mathrm{bs}} \cdot \frac{\text { styrene block percentage }}{\text { styrene block molecular weight }}}{\frac{M_{\text {was }}-M_{\mathrm{bs}}}{\text { Molecular weight of } \mathrm{SO}_{3}}} \cdot 100
$$

where $M_{\mathrm{bs}}$ membrane weight before sulfonation, $M_{\text {was }}$ membrane weight after sulfonation.

Membranes were kept in deionized water for one day and then re-weighed to determine the water uptake [9-12]. The film water uptake is the amount of water absorbed by the dry film and is calculated using Equation (2):

$\varphi=\frac{W_{1}-W_{\mathrm{k}}}{W_{\mathrm{k}}} \cdot 100$

where $\varphi$ represents the water uptake percentage of the film, $W_{1}$ is the weight of the soaked film and $W_{\mathrm{k}}$ is the weight of its dry form.

The films were immersed in $1 \mathrm{M} \mathrm{KCl}$ solution for one day and titrated with $0.0084 \mathrm{M} \mathrm{NaOH}$ solution to determine the ion-exchange capacity (IEC). IEC is the mole number of sulfonic acid groups per unit weight of the film and calculated by using Equation (3):

$\mathrm{IEC}=\frac{M_{\mathrm{NaOH}} \cdot V_{\mathrm{NaOH}}}{W_{\mathrm{memb}}}$

where $M_{\mathrm{NaOH}}$ is the concentration of the $\mathrm{NaOH}$ solution, $V_{\mathrm{NaOH}}$ is the volume used in the titration of the sample and $W_{\text {memb }}$ is the weight of the dry film. Corresponding data listed in Table 2. As suggested in the table, water uptake values of the S-SEBSL2/3/ $4 / 5$ films show a regular increment from 28.1 to $45.9 \%$ with sulfonation, which is verified by an increase in percentage sulfonation values. However, this trend seems to be not supported by a regular increase in IEC values, which displays first an increase up to $3 \mathrm{~min}-$ utes of sulfonation and then a decrease in going from 4 to 5 minutes of sulfonation. This decreasing trend in IEC values attributed to the unwanted diffusion of some sulfonated polymer chains into the $\mathrm{NaOH}$ solution into which films immersed for ion-exchange measurement, consequently ion exchange calculation gave lower values. In this point SEM EDX figures (Figure 6) were collected from the cross section 
Table 2. IEC and water uptake [\%] for sulfonated membranes

\begin{tabular}{|l|c|c|c|c|}
\hline \multicolumn{1}{|c|}{ Film names } & $\begin{array}{c}\text { Sulfonation } \\
{[\mathbf{m i n}]}\end{array}$ & $\begin{array}{c}\text { Sulfonation } \\
{[\%]}\end{array}$ & $\begin{array}{c}\text { IEC } \\
{[\mathbf{m e q} / \mathbf{g r}]}\end{array}$ & $\begin{array}{c}\text { Water uptake } \\
{[\%]}\end{array}$ \\
\hline S-SEBSL2 & 2 & 8.55 & 0.59 & 28.1 \\
\hline S-SEBSL3 & 3 & 9.51 & 0.78 & 32.9 \\
\hline S-SEBSL4 & 4 & 11.40 & 0.66 & 33.3 \\
\hline S-SEBSL5 & 5 & 12.40 & 0.61 & 75.9 \\
\hline S-SEBSH2 & 2 & 40.80 & 0.82 & 102.0 \\
\hline S-SEBSH3 & 3 & 64.50 & 1.16 & 118.0 \\
\hline S-SEBSH4 & 4 & 65.20 & 1.29 & 114.0 \\
\hline S-SEBSH5 & 5 & 97.50 & 1.62 & 121.0 \\
\hline S-SEBSH45 & 45 & 87.30 & 1.55 & - \\
\hline S-SEBSH60 & 60 & 76.40 & 1.35 & 80.0 \\
\hline Nafion 112 [6] & - & - & 0.74 & 400.0 \\
\hline Nafion 117 [6, 19] & - & - & 0.90 & \\
\hline SEBS [19] & & 55.00 & & \\
\hline
\end{tabular}

of the membranes in order to eliminate the possibility of surface sulfonation. Green color represents sulfur atoms and red color shows carbon atom from cross-section of the membranes. As can be observed from the EDX figures, sulfonation showed a depth profile rather than only surface sulfonation.

Although similar behaviour is valid for the films of S-SEBSH2/3/4/5/45/60, there is an additional effect of possible degradation by means of benzene sulfonic acid group's elimination in S-SEBSH60 at longer durations due to the corrosive nature of chlorosulfonic acid therefore decreasing the amount of detectable acid sides. This situation results in lower percentage sulfonation values, IECs and lower water uptake values than expected as seen in the Table 2 . Another point to be indicated here is that the IEC values obtained for all of the films are close or superior to those of Nafion 112 and Nafion 117 membranes. Despite their high sulfonation level water uptake values of the films showed much smaller values than the reported one $(400 \%)$ of pure SEBS in the study of Serpico et al. [24] and comparable to the Nafion 117 which could make them promising alternative in this respect.

Thermal stability which is another valuable indication of functional durability for high temperature applications in which elimination temperature of sulfonic acid groups and the maximum temperature of decomposition can be determined. In Table 3, thermal behaviours of some selected films are given. As can be observed from the first column of the table, degradation start temperature were between 380 $425^{\circ} \mathrm{C}$ which is far beyond the normal operating temperatures in fuel cells (about 25 or $80^{\circ} \mathrm{C}$ ). Thermograms of representative films are given in Fig-
Table 3. Thermal properties of the films

\begin{tabular}{|l|c|c|}
\hline Film names & $\begin{array}{c}\text { Temperature of } \\
\text { degrdation start } \\
{\left[{ }^{\circ} \mathbf{C}\right]}\end{array}$ & $\begin{array}{c}\text { Temperature of } \\
\text { maximum degredation } \\
{\left[{ }^{\circ} \mathbf{C}\right]}\end{array}$ \\
\hline S-SEBSL2 & 399 & 436 \\
\hline S-SEBSL3 & 398 & 442 \\
\hline S-SEBSL4 & 383 & 416 \\
\hline S-SEBSH2 & 432 & 461 \\
\hline S-SEBSH5 & 425 & 452 \\
\hline S-SEBSH60 & 425 & 461 \\
\hline SEBSL & 320 & 347 \\
\hline SEBSH & 302 & 432 \\
\hline Pure SEBS & 309 & 342 \\
\hline PP & 390 & 427 \\
\hline Wax & 270 & 339 \\
\hline
\end{tabular}

ure 5 in which benzene sulfonic acid elimination temperature is seen for all membranes at about $294^{\circ} \mathrm{C}$. Benzene sulfonic acid elimination is the main mechanisms of thermal degradation in these kinds of polymers. This reveals that prepared membranes will show a high thermal stability.

\subsection{Proton conductivity of sulfonated films}

Proton conductivity is an important characteristic of fuel-cell membranes and has to be maintained at high operating temperatures where the membrane moisture greatly decreases. Typical operating temperatures for a common fuel cell are 25 and $80^{\circ} \mathrm{C}$. Therefore proton conductivites of selected films were measured at 25 and at $80^{\circ} \mathrm{C}$. As seen in Table 4, all films show proton conductivities at $25^{\circ} \mathrm{C}$, which increase from 5.8 to $20.2 \mathrm{mS} / \mathrm{cm}$ for S-SEBSL2 $/ 5$ films and 115 to $405 \mathrm{mS} / \mathrm{cm}$ for S-SEBSH45/60 films. Sulfonation produces a great number of sulfonated side groups and facilitates the proton hopping between adjacent $\left(\mathrm{SO}_{3}^{-}\right)$units which supports higher 

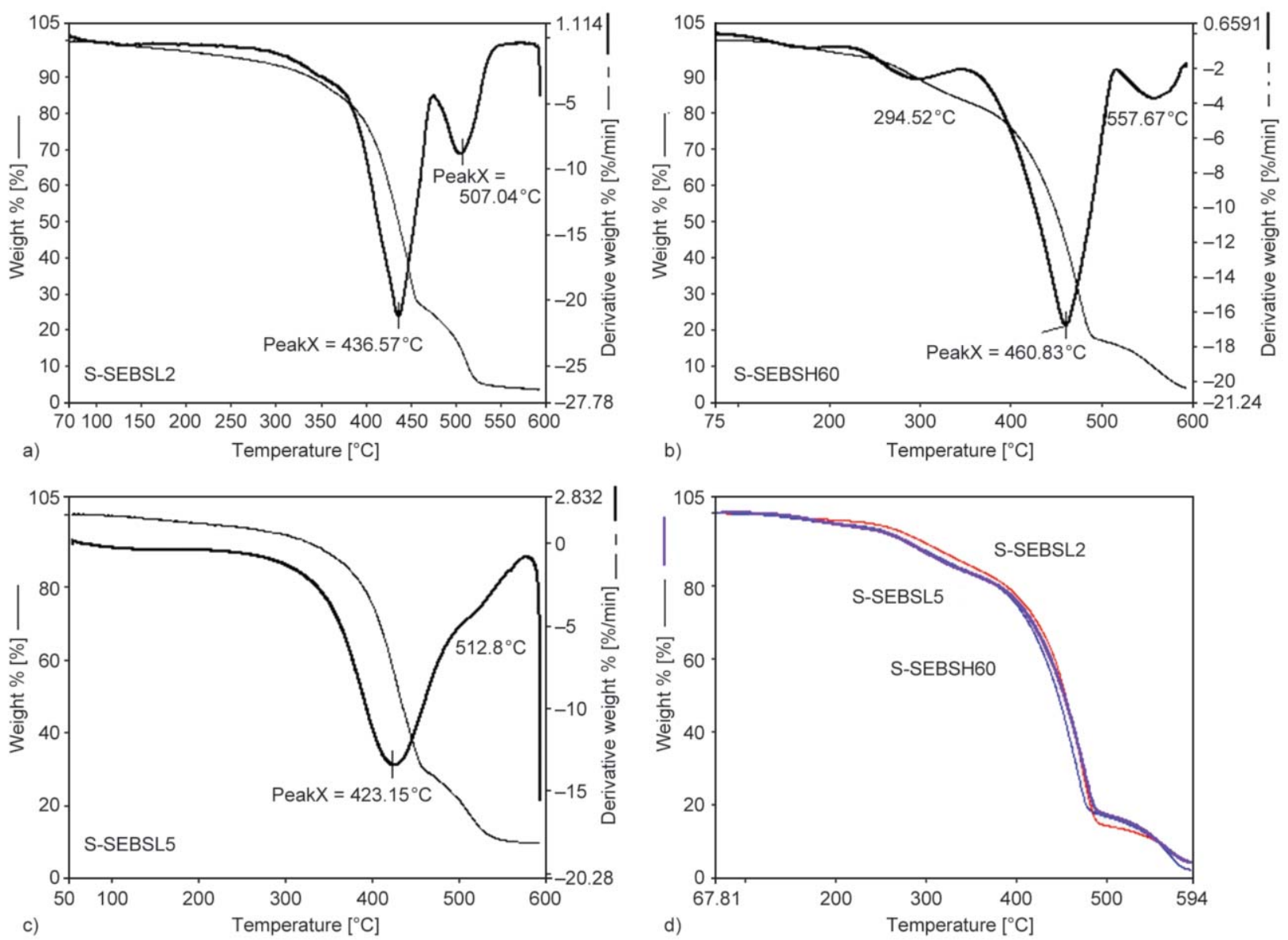

Figure 5. Thermograms of selected films a) S-SEBSL2, b) S-SEBSH60, c) S-SEBSL5, d)Comparison of benzene sulfonic acid elimination temperature for representative membranes

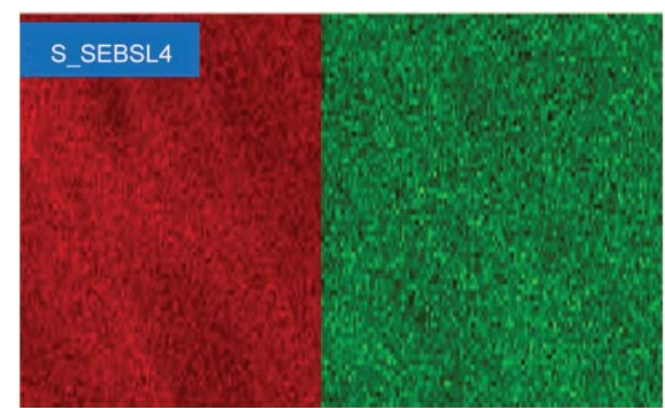

a)

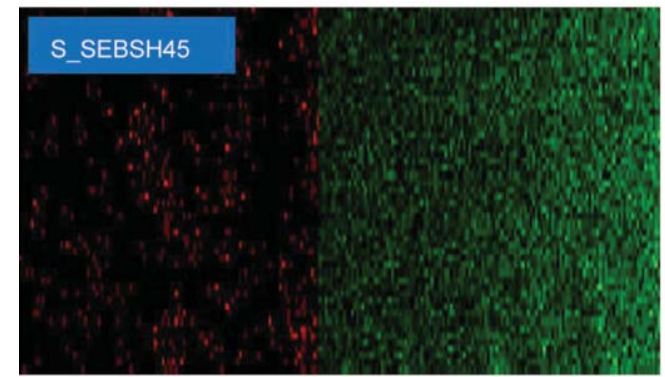

c)

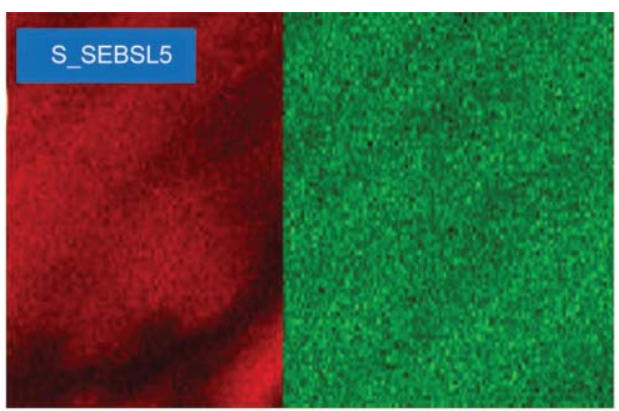

b)

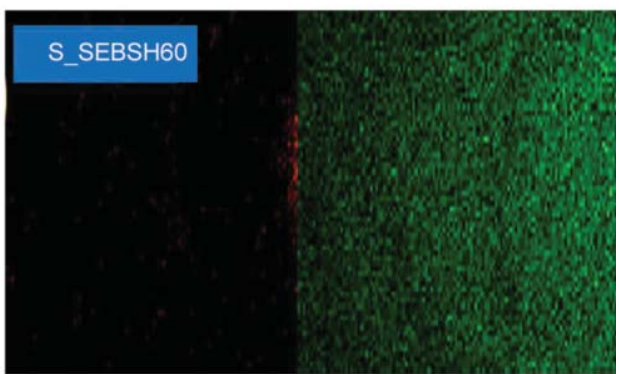

d)

Figure 6. EDX analysis from the cross section of the membranes (green: sulfur atoms, red: carbon atoms), a) S_SEBSL4, b) S-SEBSL5, c) S_SEBSH45, d) S_SEBSH60

proton conductivities [23]. Conductivities of the films were disappeared at $80^{\circ} \mathrm{C}$. Only S-SEBSH45 and SSEBSH60 films showed proton conductivity as a re- sult of large number of benzene sulfonic acid groups, which attract water molecules and increases moisture content. Styrene sulfonic acid groups are not flex- 
Table 4. Proton conductivities of sulfonated films

\begin{tabular}{|c|c|c|c|c|}
\hline \multirow{2}{*}{ Film names } & \multirow{2}{*}{$\begin{array}{c}\text { Sulfonation } \\
\text { degree } \\
{[\%]}\end{array}$} & \multirow{2}{*}{$\begin{array}{c}\text { Sulfonation } \\
\text { time } \\
\text { [min] }\end{array}$} & \multicolumn{2}{|c|}{$\begin{array}{l}\text { Proton conductivity } \\
{[\mathrm{mS} / \mathrm{cm}]}\end{array}$} \\
\hline & & & $25^{\circ} \mathrm{C}$ & $80^{\circ} \mathrm{C}$ \\
\hline S-SEBSL2 & 8.5 & 2 & 5.8 & - \\
\hline S-SEBSL5 & 12.4 & 5 & 20.2 & - \\
\hline S-SEBSH2 & 40.8 & 2 & 115.0 & - \\
\hline S-SEBSH45 & 87.3 & 45 & 432.0 & 27.2 \\
\hline S-SEBSH60 & 76.4 & 60 & 405.0 & 44.3 \\
\hline
\end{tabular}

ible side chains and do not make bending motion unlike the ether sulfonic acid groups in the Nafion, which easily bend and convey the protons although the membrane losses its whole moisture content. For this reason, if styrene sulfonic acid groups had a chance to bend, zero conductivity would not be the case from shifting 25 to $80^{\circ} \mathrm{C}$ for S-SEBSL2, SSEBSL5 and S-SEBSH2 [25].

\subsection{Scanning electron microscope (SEM) images}

SEM images of the films were taken by using JSM 5610 scanning electron microscope at $10 \mathrm{kV}$ beam voltage. As seen in the Figure 7, no microcrack formation due to high rigidity or possible phase segregation regions between hydrophobic PP/wax and hydrophilic sulfonated SEBS domains were observed. This situation suggest that sulfonated films may have a co-continuous morphology in which structurally unlike domains lies together.

\section{Conclusions}

In this study it was shown that film casting difficulty of pristine SEBS was overcome by using its blend with PP and wax. SEBS/PP blends were successfully prepared by using a twin screw extruder and were converted to very thin films for use as a potential proton-conducting membranes as $125 \mu \mathrm{m}$ thickness. By using hydrophobic PP and wax as process aid in the blend reduced the water uptake values significantly from the reported level. Young's modulus ( $E$ modulus) of the films showed an increasing tendency with sulfonation but due to moisture absorption, S-SEBSH2/3/4/5/45/60 films exhibited less rigidity than S-SEBSL2/3/4/5 films. Elongation values were found to be inversely proportional to the degree of sulfonation owing to phase segregation tunels and moisture absorption. A similiar tendency like $E$-modulus was observed in fracture stress values when sulfonation degree is increased in the range S-SEBSL2/3/4/5. However a meaningfull change was not obtained for S-SEBSH2/3/4/5/45/60 films due to high water absorption from air during measurement. A proton conductivity $405-432 \mathrm{mS} / \mathrm{cm}$ at $25^{\circ} \mathrm{C}$ is recorded but it dramatically reduced to $27.2-44.3 \mathrm{mS} / \mathrm{cm}$ when the

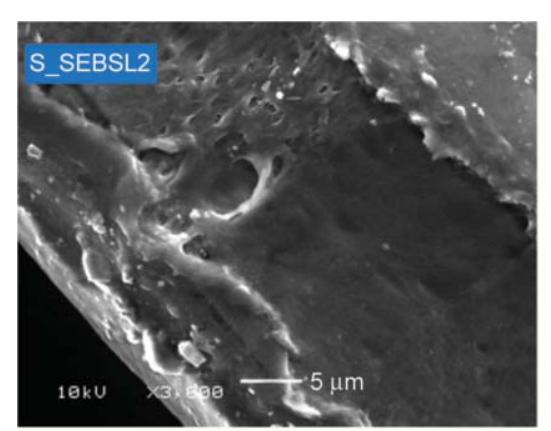

a)

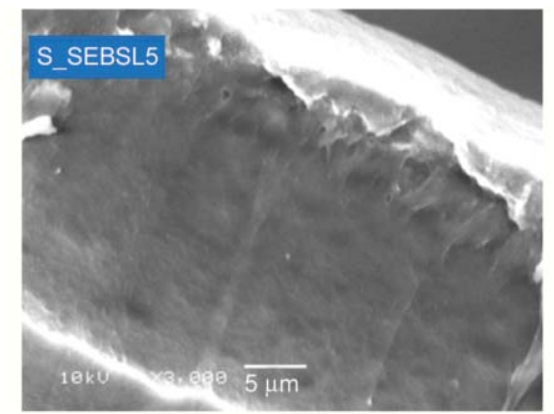

b)

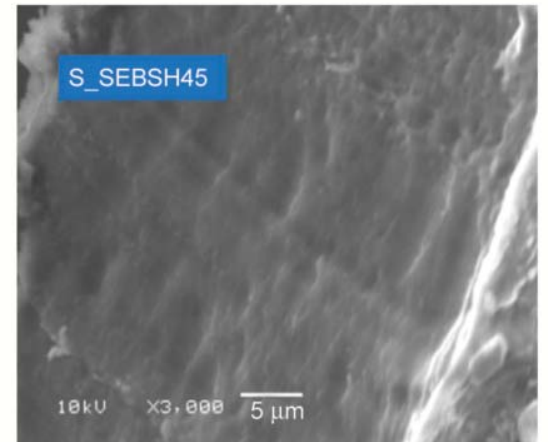

d)

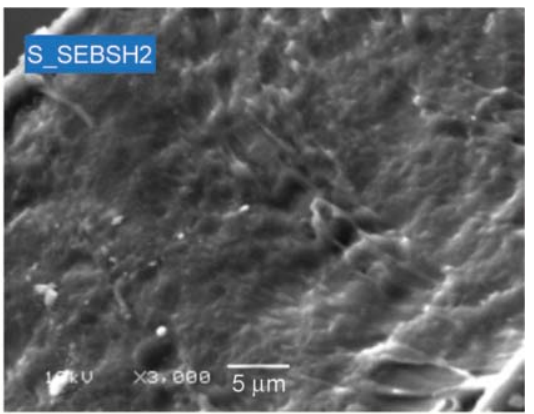

c)

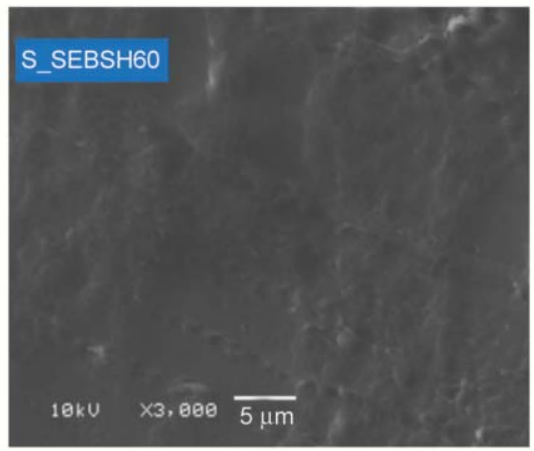

e)

Figure 7. SEM images of the films given in Table 4, a) S_SEBSL2, b) S_SEBSL5, c) S_SEBSH2, d) S_SEBSH45, e) S_SEBSH60 
temperature was elevated to $80^{\circ} \mathrm{C}$ due to the unability of films to retain their moisture content. It can be concluded that with improved water uptake values and higher proton conductivities, prepared films of SEBS blends seem to be promising low cost alternative. However in situ fuel cell tests have to be carried out in order to examine the cyclic thermo-mechanical durability and thermo-chemical resistance for making more precise conclusion about their usability as proton exchange membrane.

\section{Acknowledgements}

The authors gratefully acknowledge financial support through the TUBITAK Research Project TBAG-112T628 and Hacettepe University 010D05601.001 project. The authors also wish to thank the UNIDO-ICHET Turkey branch for permission to use the laboratories and Gülşah Yeğen Özalp for his help.

\section{References}

[1] Healy J., Hayden C., Xie T., Olson K., Waldo R., Brundage M., Gasteiger H., Abbott J.: Aspects of the chemical degradation of PFSA ionomers used in PEM fuel cells. Fuel Cells, 5, 302-308 (2005).

https://doi.org/10.1002/fuce.200400050

[2] Wilkinson D. P., Zhang J., Hui R., Fergus J., Li X.: Proton exchange membrane fuel cells: Materials properties and performance. CRC Press, London (2009).

[3] Singha S., Jana T., Modestra J. A., Kumar A. N., Mohan S. V.: Highly efficient sulfonated polybenzimidazole as a proton exchange membrane for microbial fuel cells. Journal of Power Sources, 317, 143-152 (2016). https://doi.org/10.1016/j.jpowsour.2016.03.103

[4] Watanabe M., Tsurumi K., Mizukami T., Nakamura T., Stonhart P.: Activity and stability of ordered and disordered Co-Pt alloys for phosphoric acid fuel cells. Journal of the Electrochemical Society, 141, 2659-2668 (1994). https://doi.org/10.1149/1.2059162

[5] Lysova A. A., Ponomarev I. I., Yaroslavtsev A. B.: Composite materials based on polybenzimidazole and inorganic oxides. Solid State Ionics, 188, 132-134 (2011). https://doi.org/10.1016/j.ssi.2010.10.010

[6] Maity S., Jana T.: Soluble polybenzimidazoles for PEM: Synthesized from efficient, inexpensive, readily accessible alternative tetraamine monomer. Macromolecules, 46, 6814-6823 (2013). https://doi.org/10.1021/ma401404c

[7] Ghosh S., Sannigrahi A., Maity S., Jana T.: Role of clays structures on the polybenzimidazole nanocomposites: Potential membranes for the use in polymer electrolyte membrane fuel cell. Journal of Physical Chemistry C, 115, 11474-11483 (2011). https://doi.org/10.1021/jp202672s

[8] Holden G., Kricheldorf H. R., Quirk P. R.: Thermoplastic elastomers. Hanser, Cincinnati (2004).
[9] Kim J., Kim B., Jung B.: Proton conductivities and methanol permeabilities of membranes made from partially sulfonated polystyrene-block-poly(ethylene-ranbutylene)-block-polystyrene copolymers. Journal of Membrane Science, 207, 129-137 (2002).

https://doi.org/10.1016/S0376-7388(02)00138-2

[10] Hwang H. Y., Koh H. C., Rhim J. W., Nam S. Y.: Preparation of sulfonated SEBS block copolymer membranes and their permeation properties. Desalination, 233, 173182 (2008).

https://doi.org/10.1016/j.desal.2007.09.040

[11] Mokrini A., Huneault M. A.: Proton exchange membranes based on PVDF/SEBS blends. Journal of Power Sources, 154, 51-58 (2006).

https://doi.org/10.1016/j.jpowsour.2005.04.021

[12] Mokrini A., Huneault M. A., Shi Z., Xie Z., Holdcroft S.: Non-fluorinated proton-exchange membranes based on melt extruded SEBS/HDPE blends. Journal of Membrane Science, 325, 749-757 (2008). https://doi.org/10.1016/j.memsci.2008.08.051

[13] Sengupta P.: Morphology of thermoplastic elastomer blends. PhD Thesis. University of Twente, Enschede (2004).

[14] Venestra H., van Lent B. J. J., van Dam J., de Boer A. P.: Co-continuous morphologies in polymer blends with SEBS block copolymers. Polymer, 40, 6661-6672 (1999).

https://doi.org/10.1016/S0032-3861(98)00875-1

[15] Mae H., Omiya M.: Toughening mechanism of pp with bimodal distributed SEBS particle size. in 'Proceedings of $\mathrm{XI}^{\text {th }}$ International Congress and Exposition Orlando, USA' p.7 (2008).

[16] Ohlsson B., Hassender H., Törnell B.: Blends and thermoplastic interpenetrating polymer networks of polypropylene and polystyrene-block-poly(ethylene-statbutylene)-block-polystyrene triblock copolymer. 1:Morphology and structure-related properties. Polymer Engineering and Science, 36, 501-510 (1996).

https://doi.org/10.1002/pen.10436

[17] Sengupta P., Noordermeer J. W. M.: A comparative study of different techniques for microstructural characterization of oil extended thermoplastic elastomer blends. Polymer, 46, 12298-12305 (2005). https://doi.org/10.1016/j.polymer.2005.10.075

[18] Polat K.: Development of styrene-(ethylene-buthylene)styrene (SEBS) based composite polyelectrolyte membrane. PhD. Thesis, Hacettepe University, Ankara (2013).

[19] Kwee T., Mauritz K. A., Beyer F. L.: Poly[styrene- $b$ maleated (ethylene/butylene)- $b$-styrene] (mSEBS) block copolymers and mSEBS/inorganic nanocomposites: I. Morphology and FTIR characterization. Polymer, 46, 3871-3883 (2005).

https://doi.org/10.1016/j.polymer.2005.02.076

[20] Ganguly A., Bhowmick A. T.: Sulfonated styrene-(ethylene-co-butylene)-styrene/montmorillonite clay nanocomposites: Synthesis, morphology, and properties. Nanoscale Research Letters, 3, 36-44 (2007). https://doi.org/10.1007/s11671-007-9111-3 
[21] Munteanu S. B., Vasile C.: Spectral and thermal characterization of styrenebutadiene copolymers with different architectures. Optoelectronics and Advanced Materials-Rapid Communications, 7, 3135-3148 (2005).

[22] Wu S., Peng S., Hameed N., Guo Q., Mai Y-W.: A new route to nanostructured thermosets with block ionomer complexes. Soft Matter, 8, 688-698 (2012).

https://doi.org/10.1039/C1SM06244A

[23] Peckam T. P., Schmeisser J., Rodgers M., Holdcroft S.: Main-chain, statistically sulfonated proton exchange membranes: The relationships of acid concentration and proton mobility to water content and their effect upon proton conductivity. Journal of Materials Chemistry, 17, 3255-3268 (2007).

https://doi.org/10.1039/B702339A
[24] Serpico J. M., Ehrenberg S. G., Fontanella J. J., Jiao X., Perahia D., McGrady K. A., Sanders E. H., Kellogg G. E., Wnek G. E.: Transport and structural studies of sulfonated styrene-ethylene copolymer membranes. Macromolecules, 35, 5916-5921 (2002).

https://doi.org/10.1021/ma020251n

[25] Huang X., Solasi R., Zou Y., Feshler M., Reifsnider K., Condit D., Burlatsky S., Madden T.: Mechanical endurance of polymer electrolyte membrane and PEM fuel cell durability. Journal of Polymer Science Part B: Polymer Physics, 44, 2346-2357 (2006). https://doi.org/10.1002/polb.20863 